\title{
Islamic Religious Coping, Partner Support and Parenting Stress On Mothers Who Accompany Their Children Study From Home in a Covid-19 Pandemic Situation
}

\author{
Rahma Kusuma Fitri ${ }^{1}$, Fuad Nashori ${ }^{2}$ \\ Universitas Islam Indonesia Yogyakarta \\ Email: ${ }^{1}$ rahmakusumafitri@gmail.com, ${ }^{2}$ fuadnashori@uii.ac.id
}

\begin{abstract}
One of the impacts of the COVID-19 pandemic on the education and family sector is that children are required to study from home (SFH) or online. This condition makes the burden of a mother's responsibility increase because she has to be both a mother and a teacher for her children, where these demands cause mothers to experience parenting stress. This study aims to determine how big the contribution of Islamic religious coping variables and partner support to parenting stress. This study used quantitative research methods with a three-variable correlation research design. The research respondents were 319 mothers in Indonesia with an age range between 26 and 51 years old. The measuring instrument used is Islamic religious coping short-form (IRCS) Raiya (2008), Receipt of Spousal Support Scale (RSSS) from Dorio (2010), and the Parenting Stress Scale (PSS) from Berry and Jones (1995). The research data were analyzed using the SPSS 26 statistical analysis program with multiple linear regression test techniques to answer the research hypothesis. The results showed that there was a significant negative contribution of Islamic religious coping and partner support to parenting stress for mothers who accompanied SFH children in the COVID-19 pandemic situation.
\end{abstract}

Keywords: Islamic Religious Coping, Partner Support, Parenting Stress, Study From Home (SFH), COVID-19 Pandemic

\begin{tabular}{|c|c|c|c|c|}
\hline Submission & Review Process & Revised & Accepted & Published \\
\hline February 15, 2021 & $\begin{array}{c}\text { April 6, 2021 - May } \\
\text { 15, 2021 }\end{array}$ & June 3, 2021 & June 7, 2021 & June 30, 2021 \\
\hline
\end{tabular}

\section{Introduction}

The Coronavirus pandemic is a phenomenon that causes serious concern to all people around the world. The World Health Organization (WHO, 2020) states that a new type of Coronavirus causes COVID-19 which is an infectious disease. This virus was unknown before the outbreak began in Wuhan, China, in December 2019. Currently, COVID19 has become a worldwide pandemic (WHO, 2020). The United Nations Children's Fund (UNICEF, 2020) stated that the phenomenon of the COVID-19 pandemic was first detected in Indonesia on March 2, 2020. This condition requires all countries including Indonesia to limit physical interaction (physical distancing) to prevent the spread of COVID - 19 .

UNICEF (2020) stated that the various efforts to prevent the spread of COVID-19 had a significant impact on the social, economic, educational, daily activities and all aspects of children's lives, especially in Indonesia. Furthermore, UNICEF (2020) states that some of the impacts of COVID-19 on children in Indonesia can be grouped into four categories, (i) nurturing and security, (ii) learning, (iii) child poverty, and (iv) nutrition.

One of the impacts of COVID-19 on the education sector in Indonesia is that children are required to study from home (SFH) or online. This condition requires parents to accompany their children to study at home. Parental assistance in studying at home is certainly needed by children in the Kindergarten and Elementary School, which are in the age range between four and twelve years. The children in the group need quite intense assistance from their parents because 
they still need direction in understanding the learning material. This is different from older children who can independently participate in online learning at home. Older children are considered to be less in need of assistance from their parents.

The results of a survey conducted by researchers (as a preliminary study of this research) in November 2020 of 196 mothers in a junior high school in Yogyakarta, showed that mothers with junior high school children tended to experience less pressure in accompanying children to learn online. Mothers admit that they often have difficulty accompanying their children to learn online then $81 \%$ enjoy the online learning process by their children in a relaxed manner.

Qualitatively, mothers with junior high school children tend to be more relaxed in accompanying children to learn online than mothers with younger children. It showed that mothers with junior high school children tend to experience less pressure in accompanying children to learn online. Mothers admit that they often have difficulty accompanying their children to learn online and $81 \%$ enjoy the online learning process by their children in a relaxed manner. Qualitatively, mothers with junior high school children tend to be more relaxed in accompanying children to learn online than mothers with younger children.

The online learning process that children of kindergarten-elementary age have its psychological impact on parents, especially mothers. The results of a survey by the Indonesian Child Protection Commission (Komisi Perlindungan Anak Indonesia KPAI) involving parents and child respondents in 34 provinces in Indonesia found that parenting in Indonesia is more dominantly carried out by mothers (Tirto.id, 2020). Research in Indonesia conducted by Mariani et al (2020) found that the COVID-19 pandemic situation resulted in mothers experiencing stress in raising children, thus requiring greater efforts to improve their psychological wellbeing.

During the pandemic, mothers often accompany their children to study at home and do other activities. Meanwhile, as many as $21 \%$ of fathers never accompany their children to study at home and $17.5 \%$ of fathers never accompany their children to do the activities.

The interesting thing is that although children in Indonesia are more often cared for and interact with their mothers, children admit that they often experience violence from their mothers, 39.8\% have been pinched, $19.5 \%$ have been teased, 10, 6\% had been hit, and $7.7 \%$ had been drawn. In terms of the perpetrators, the children mentioned that physical violence was carried out by the mother $(60.4 \%)$, brother or sister $(36,5 \%)$, and father $(27.4 \%)$. Meanwhile, in terms of parents, as many as $32.3 \%$ of fathers and $42.5 \%$ of mothers admitted to committing physical violence (Tirto.id, 2020).

In addition to physical violence, children often experience psychological violence, such as being scolded (56\%), compared to other children (34\%), being yelled (23\%), and being glared (13\%). The results of the recognition of children who were respondents in the survey, as many as $79 \%$ of mothers committed psychological violence. $42 \%$ is done by the father and $20.4 \%$ is done by brother or sister. $73 \%$ of mothers who were respondents in the survey admitted to committing psychological violence and $69.6 \%$ of fathers participated (Tirto.id, 2020).

Furthermore, KPAI explained that the increase in violence against children during this pandemic was due to the greater responsibility for child care that rested on the mother. Not to mention, mothers have to bear the heavy domestic and psychological burden during the pandemic. On the other hand, fathers are less burdened in parenting. The violence that led to the loss of a child's life also occurred in Indonesia. In August 2020, a 
mother killed her 8-year-old son because she was annoyed that his son had difficulty understanding the material while studying at home. The mother then abused her child to death (Kompas, 2020).

Observational and interview data that the researchers found (as a preliminary study of this research) in November 2020 show that there is an impact of online learning assistance on working mothers and housewives. In working mothers, the impact felt in the form of difficulty dividing time, so that working mothers felt rushed, thoughts became more complicated, had to divide time and increased responsibilities, felt annoyed, angry with children, disappointed, heart palpitations and felt headaches, and feeling guilty about having to work from morning until noon.

The impacts that arise are several forms of symptoms of parenting stress. Sometimes even working mothers have to take their children to the office to keep track of online schooling. Some working mothers feel pressure because their husbands do not want and or cannot accompany their children to study online so that in the afternoon or evening working mothers still have to accompany their children to do the tasks assigned by the school. Some mothers are even forced to do tasks that should be done by their children because at night, the children are tired and sleepy.

For housewives, as obtained from a preliminary survey conducted by researchers, the perceived impact of online learning assistance is in the form of increasing domestic tasks that must be done, for example during normal conditions before the pandemic, housewives do domestic work every day such as cleaning the house, cooking and so on. The online learning that their children do adds to the duties of housewives so that other domestic work becomes neglected. Moreover, for mothers who have several other small children who must also be cared for or accompanied by online learning.
For mothers with lower educational levels, as obtained by researchers from the preliminary survey, the implementation of online schools also has its impact. This is related to masterys of technology such as gadgets. Mothers who are not used to using various online learning media, such as Google Forms, Google Meet, Zoom, and the like, will have difficulty. Difficulties are also experienced by mothers with lower economic status because online schools require a fairly large internet quota fee. Not only psychological impacts such as anger, upset, disappointment, and depression, the physical impact is also felt by housewives. Housewives complain that they often feel dizzy, heart palpitations, and stomach pains when accompanying children to learn online during the pandemic. Not only psychological impacts such as anger, upset, disappointment, and depression, the physical impact is also felt by housewives.

One of the obstacles that both working mothers and housewives experience is the dual role of mothers and teachers at home. Mothers have difficulty accompanying and helping their children teach certain subject matter, such as mathematics which requires mastery of certain techniques or other subjects. Mothers also complained about the difficulty of accompanying online learning because previously they did not have knowledge about children's education and how to teach it. This phenomenon is known as parenting stress.

Parenting stress, first expressed by Abidin et al, (2013), is a feeling of anxiety and tension that goes beyond the limits and is especially related to the role and interaction of parents with children. Parenting stress arises when parents have difficulty meeting the demands of being a parent so that it affects the behavior, welfare, and adjustment of children. (Berry \& Jones, 1995). Deater and Deckard (2004) explain that the characteristics of a person experiencing parenting stress are 
decreased quality and effectiveness of parenting behaviors, such as reduced expressions of warmth and affection, reduced consistency of parenting behavior, and increased harsh disciplinary methods and expressions of hostility towards children.

In taking care of children, mothers are more likely to experience difficulties compared to fathers. One of the contributing factors is the emergence of pressure on mothers because mothers spend more time and interact with children in various activities (Zarei et al, 2010). Parenting stress experienced by mothers has several effects that cannot be underestimated. The stress felt by the mother can have an impact on the mother's behavior towards her child, which ultimately affects the low quality of the mother's care for her child (Deater \& Deckard, 2004).

Aini et al (2020) found the impact of prolonged parenting stress, which can trigger violent behavior of parents against children. The higher the level of parenting stress, the greater the possibility of violent behavior towards children (Ratnasari \& Kuntoro, 2017). Parenting stress also causes depression in parents (Hastings et al, 2006). Children whose parents experience parenting stress tend to suffer socially, emotionally, behaviorally, and developmentally because parenting stress negatively affects parents' perceptions of their children's behavior. (Plant \& Sanders, 2007). Research conducted by David and Kiang (2020) found that in particular, parenting stress significantly and negatively predicted maternal well-being, but religious coping, social support, and spirituality did not show significant primary or interactive effects. Furthermore, the study suggests that future researchers should study further the potential role of religious coping as a source of resilience in the child-rearing process.

Factors that also influence parenting stress are the individual's ability to design strategies to manage stress and problem solving, maternal psychological well-being, marital status, marital satisfaction, and behavioral or child health problems. (Johnston et al., 2003). In addition, social support is also a factor that is negatively correlated with parenting stress (Pinderhughes et al, 2000). Parenting stress is also caused by the socioeconomic status of the family as seen from the education, income, and occupation of the parents (Brooks, 2011). Other factors that influence parenting stress are gender and individual differences. First, gender, which is how father and mother are involved in each other in carrying out household responsibilities including taking care of children. Parents who are not involved with each other in completing household responsibilities, this condition will be more prone to triggering parenting stress than parents who are involved in completing household responsibilities. Second, individual differences.

This is related to individual differences between fathers and mothers in their experience of being cared for by their previous parents so that it affects the child-rearing process. Differences in how to manage stress also affect the incidence of parenting stress between parents. Understanding individual differences between parents are critical when relating them to difficulties in parenting roles. Each parent has a different vulnerability to stress, which comes from biological and environmental influences (Dearter \& Deckard, 2004).

Islamic religious coping is one of the important variables that affect parenting stress. Previous research has found that religiosity has been shown to have a close relationship with more effective parenting, parental warmth, and family cohesiveness (Mahoney, 2010). The results of empirical research also show that parental religiosity is negatively correlated with the emergence of symptoms of parenting stress such as shouting at preschool and elementary school-age children. (Wilcox, 
2002). On the other hand, the results of other empirical studies also show that positive religious coping plays a beneficial role in the lives of Muslims in dealing with life stressors. Raiya et al, 2008; Aflakseir and Coleman, 2009; Ai et al, 2009; Khan et al, 2012). Achour and Boerhannoeddin (2011) argue that Islamic positive religious coping is a problem management strategy by believing in the power of God and His love is far greater than the problems experienced by humans. God will always provide a way out of every problem to return the harmony in life. Raiya (2008) mentions that there are two aspects of Islamic religious coping. First, Islamic positive religious coping is a religious coping method that reflects a positive relationship with God and the belief that there is meaning or wisdom from an event. Second, Islamic negative religious coping, which is a coping method that reflects a negative relationship with God, is related to how a person's perception of God is when problems are afflicted. For example, does a person believe that the problems that befall him are a punishment from Allah for sins that have been committed before? Stella and Chima (2015) found that Islamic positive religious coping makes it easier for a person to balance and even reduce conflicts in the demands of work and family responsibilities.

In Islamic teachings, the existence of trials and problems of life is human nature. Allah has made it clear in the Qur'an, Surah AlBaqarah:155-156, that humans will be tested with some problems, but Allah will give good news to His servants who remember Allah when troubles befall them.

Meaning: "And We will surely test you with something of fear an hunger an a loss of wealth and lives an fruits, but give good tidings to the patient, Who, when disaster strikes them, say: "Inna lillahi wa innaa ilaihi raaji'uun". (QS. al-Baqarah: 155-156).

The verse explains that Allah will test His servants with various fears, hunger, lack of wealth, lives, and fruits (food ingredients). Through this test, it is hoped that Muslims will become mentally strong, strong in their beliefs, steadfast in their souls, and withstand trials. Muslims who can pass the test will get the title of a patient person and will receive good news from Allah. Furthermore, in verse 156, Allah ordered the Prophet Muhammad SAW to tell the characteristics of those who receive good news, namely those who are patient when calamity befalls them by saying: "Indeed we belong to Allah and Him we return" (Ministry of Religious Affairs). RI, 1971). Likewise concerning a mother who takes care of children in this pandemic situation.

Besides Islamic religious coping, another factor that plays a role in parenting stress is partner support. Dorio (2010) explained that there are two sources of support, support from work (supervisors, coworkers, or organizations) and outside work (partner, family, and friends). Patel et al (2008) said that partner support is encouragement or motivation given by a partner or close person.

Dorio (2010) said that there are four aspects of partner support. First, emotional concern can be given through caring, empathy, love, affection, and trust. Second, instrumental support in the form of assistance to partners when they need help, experiencing difficulties, or simply helping to ease their partner's tasks. Third, informational support, which can be provided by a partner to solve problems, such as providing advice or direction to a partner. Fourth, appraisal support, by giving awards to partners through praise or criticism or feedback as a partner's self-evaluation.

Social support, which includes partner support, is the most important factor associated with parenting stress (Kanter \& Proulx, 2019). Partner support was found to be significantly associated with life satisfaction with mediated parental stress (Lu et al, 2018). Social support, especially support from a partner, is an effective factor that can affect parenting stress. 
If the partner provides positive support, it can minimize parenting stress (Boyd, 2002). Various previous research results showed that social support is positively related to the meaning of life (Siddik et al, 2018), quality of life (Sari et al, 2018), and subjective wellbeing (Hasibuan et al, 2018).

The importance of the role of the husband or father in supporting the parenting process has also been explained in several verses of the Qur'an, even Allah immortalizes various examples of fathers who play a role in raising their children, such as Luqman, Prophet Ibrahim, and Prophet Noah. In Surah Luqman:13, Allah immortalizes the figure of Luqman who plays a very important role in the formation of the character and aqidah of his son. The verse reads: and (remember) when Luqman said to his son while he admonished him: "O my dear son, do not associate anything with Allah, most surely ascribing partners (to Allah) is a tremendous torment" (QS. Luqman: 13).

This verse emphasizes that the obligation of fathers to their children is to give advice and lessons so that their children take the right path and do not fall into error. In addition to noble character, children are expected to inherit and have all the values and beliefs that their father followed. As a father, Lukman has carried out a very important task for his son, namely conveying true religion and noble character.

Lukman's way of giving advice and lessons to his children is a good example for every parent, especially a father who claims to be a Muslim (Depag RI, 1971). Concerning parenting stress, this verse emphasizes the importance of the father's role in raising children. Through the involvement of the father in parenting, there will be a balance of parenting roles, According to Shihab (2009), the word بعظه (to teach) is taken from the word و عظ, which means advice on various virtues in a way that touches the heart. This word also means that the advice is carried out from time to time, as understood from the present tense and comes to the word يعظه.

A father not only has the responsibility of raising children in this world but a father will also be held accountable in the hereafter. This is as stated by the Prophet Muhammad SAW in a hadith narrated by Muslim (AlHajjaj, 2008), which means: "A man (father) is the leader for his family and he is responsible for all of them." (HR. Muslim).

Islamic religious coping and partner support found in several studies above are two important factors that influence parenting stress, so these two things become important to be investigated further. In addition, in an Islamic perspective, these two factors are important and inseparable in the parenting process because Islamic religious coping is an important capital for mothers in the realm of belief and hablumminallah (belief and relationship with Allah). Partner support is important in contributing to parenting stress because it is one of the real realms where humans need interaction and support with other humans. After all, it is human nature as a social being. In the Islamic perspective, humans are encouraged to maintain hablumminannaas (relationships with humans) and help each other in kindness and patience (QS. al-Maidah: 2; QS. al-'Asr: 3).

Based on the explanation above, the purpose of this study can be formulated, namely to examine more deeply about the influence of Islamic religious coping and partner support on parenting stress in mothers who accompany SFH children in the COVID19 pandemic situation. Furthermore, the researcher proposed a research hypothesis that Islamic religious coping and partner support contributed negatively to parenting stress. 


\section{Research Method \\ Research Subject}

The subjects of this study amounted to 319 people who were selected with certain criteria, living in Indonesia, Muslim, having a husband, having children aged 4-12 years who did a study from home (SFH). The demographic characteristics of the research subjects were revealed in this study, including the number of children, education level, employment status, and total family income.

The research subject search technique was carried out by purposive sampling, which is sampling by selecting groups of subjects based on certain characteristics or traits that had a close relationship with the characteristics or characteristics of the population that had been previously known (Hadi, 2004).

\section{Data collection}

The data collection method was carried out through a Google Form which contained three research scales, the Islamic religious coping short-form (IRCS) scale which was designed by Raiya (2008), regarding the construct of religious coping by Pargament et al, (2000). This scale consists of two aspects, Islamic negative religious coping which consists of 7 items, with a reliability of $0.92-$ 0.95 , and Islamic positive religious coping which consists of 5 items, with a reliability of 0.74. Some examples of items on the IRCS scale include: "When I have problems in life, I come closer to Allah SWT; When I have a problem, I think about what I've done, so God punishes me."

Designed Receipt of Spousal Support Scale (RSSS) pair support scale Dorio (2010) created based on the pair support construct by Greenhaus et al, (1990) and House's (Dorio, 2010). The number of items consists of 20 items, with Cronbach's Alpha reliability known to be 0.92 . Some examples of these RSSS scale items include: "My husband regularly asks how I am; When I told a story, my husband doesn't listen seriously.

Parenting Stress Scale (PSS) was developed by Berry and Jones (1995) totaling 18 items. The reliability of Cronbach's Alpha is known to be 0.83 . PSS content validity was rated very well and each item was able to represent aspects of parenting stress (Holly et al, 2019). Some examples of these PSS scale items are: "I am happy to play the role of a parent; The biggest source of stress in my life is my children."

\section{Data analysis}

The researcher uses multiple linear regression data analysis techniques that aim to predict the condition of the dependent variable (criteria) if two or more independent variables as predictor factors are manipulated (Sugiyono, 2019). Multiple linear regression was performed to increase the probability of prediction involving multiple predictors (Elmes et al, 2014). The data obtained from the research results were analyzed using the SPSS 26 program with multiple linear regression test techniques to prove the research hypothesis.

\section{Results}

\section{Demographic Data of Research Subjects}

Table 1.

Demographic Data of Research Subjects

\begin{tabular}{|c|c|c|c|}
\hline Characteristics & Category & $\mathbf{N}$ & $\%$ \\
\hline \multirow{2}{*}{ Age } & 26-40 years old & 258 & $81 \%$ \\
\hline & $31-51$ years old & 61 & $19 \%$ \\
\hline \multirow{2}{*}{$\begin{array}{l}\text { Number } \\
\text { children }\end{array}$} & $1-4$ & 315 & $99 \%$ \\
\hline & $>5$ & 4 & $1 \%$ \\
\hline \multirow{3}{*}{$\begin{array}{l}\text { Level } \\
\text { education }\end{array}$} & $\begin{array}{l}\text { Elementary-high } \\
\text { school }\end{array}$ & 49 & $15.4 \%$ \\
\hline & $\begin{array}{l}\text { Undergraduate } \\
\text { diploma }\end{array}$ & 222 & $69.6 \%$ \\
\hline & Master-Doctor & 48 & $15.1 \%$ \\
\hline \multirow{2}{*}{ Job-status } & Housewife & 152 & $47.6 \%$ \\
\hline & Work & 167 & $52.4 \%$ \\
\hline Economic Status & Low & 55 & $17.2 \%$ \\
\hline
\end{tabular}




\begin{tabular}{cccc}
\hline & Middle & 132 & $41.4 \%$ \\
\cline { 2 - 3 } & High & 132 & $41.4 \%$ \\
\hline Total & 319 & $100 \%$ \\
\hline
\end{tabular}

Table 1 above shows the number of research subjects in demographic characteristics. Based on the table, it can be concluded that the majority of the subjects in this study were $26-40$ years old $(81 \%)$, had 14 children (99\%), had a bachelor's/diploma education (69.6\%), worked as a working mother $(52.4 \%)$, and are in the middle $(41.4 \%)$ and lower $(41.4 \%)$.

\section{Categorization of Research Subjects}

Table 2.

Categorization of Research Subjects

\begin{tabular}{|c|c|c|c|c|c|c|}
\hline \multirow[t]{2}{*}{ Category } & \multicolumn{2}{|c|}{$\begin{array}{l}\text { Islamic } \\
\text { religious } \\
\text { coping }\end{array}$} & \multicolumn{2}{|c|}{$\begin{array}{l}\text { Partner } \\
\text { Support }\end{array}$} & \multicolumn{2}{|c|}{$\begin{array}{c}\text { Parenting } \\
\text { Stress }\end{array}$} \\
\hline & $\mathbf{N}$ & $\%$ & $\mathbf{N}$ & $\%$ & $\mathbf{N}$ & $\%$ \\
\hline High & 73 & $21.8 \%$ & 51 & $15.2 \%$ & 61 & $18.2 \%$ \\
\hline Mediun & 222 & $66.3 \%$ & 229 & $68.4 \%$ & 224 & 66.9 \\
\hline Low & 24 & $7.2 \%$ & 39 & $11.6 \%$ & 34 & $10.1 \%$ \\
\hline Total: & 319 & $100 \%$ & 319 & $100 \%$ & 319 & $100 \%$ \\
\hline
\end{tabular}

Table 2 shows the percentage distribution of subject categories in each variable. It is known that the categorization of subjects in the Islamic religious coping variable has a percentage of $21.8 \%$ (high category), $66.3 \%$ (medium category), $7.2 \%$ (low category). On the partner support variable, the percentage of research subjects was $15.2 \%$ (high category), $68.4 \%$ (medium category), and $11.6 \%$ (low category). Furthermore, on the parenting stress variable, the percentage of research subjects was $18.2 \%$ (high category), $66.9 \%$ (medium category), and $10.1 \%$ (low category).

\section{Assumption Test Results}

Before testing the hypothesis, the researcher tested the assumptions first as a condition for the multiple regression test.
Assumption tests carried out include normality, linearity, multicollinearity, and heteroscedasticity tests. The results of the normality test showed that the variable data on Islamic religious coping, partner support, and parenting stress were normally distributed with a significance value of 0.063 ( $p>0.05)$. In the linearity test, it is known that the significance value is 0.655 ( $p>0.05$ ), so it can be concluded that there is a linear relationship between Islamic religious coping variables and parenting stress. Linear test on the variables of partner support and parenting stress obtained a significance value of 0.133 ( $>>0.05)$, so there is a linear relationship between the two variables.

In the multicollinearity test, it is known that the tolerance value is $1,000(>0.10)$ and the VIF value is $1,000(<10)$. So, referring to the basis of decision making in the multicollinearity test, it can be concluded that there are no symptoms of multicollinearity in the regression model. Furthermore, in the heteroscedasticity test, it is known that the significance value of the partner support variable is $0.077(p>0.05)$. Meanwhile, the significance value of the Islamic religious coping variable is $0.126(p>0.05)$. These results indicate that there is no symptom of heteroscedasticity in the regression model.

\section{Hypothesis Test Results}

The results of this research hypothesis test can be seen in the following table:

Table 4

Hypothesis Test Results

\begin{tabular}{|c|c|c|c|c|c|}
\hline \multicolumn{6}{|c|}{ ANOVA } \\
\hline Variable & B & $\mathbf{t}$ & Sig. & $\begin{array}{l}\text { Adjusted } \\
\text { R Square }\end{array}$ & $\begin{array}{c}\text { Sig. } \\
\text { F }\end{array}$ \\
\hline (Constant) & 61,967 & & & & \\
\hline $\begin{array}{l}\text { Islamic } \\
\text { religious } \\
\text { coping }\end{array}$ & -.291 & 3,000 & .003 & .164 & .000 \\
\hline $\begin{array}{l}\text { Partner } \\
\text { support }\end{array}$ & -.240 & $\begin{array}{c}- \\
7.383 \\
\end{array}$ & .000 & .164 & .000 \\
\hline $\begin{array}{l}\text { Dependent } \\
\text { variable: }\end{array}$ & & arer & 0 & & \\
\hline
\end{tabular}


Table 4 above shows the significant value of the Islamic religious coping variable of 0.003 ( $p<0.05)$, which means that Islamic religious coping has a negative contribution to parenting stress (regression value of -.291 indicates there is a negative contribution of Islamic religious coping to parenting stress). The higher the level of Islamic religious coping, the lower the parenting stress. Furthermore, it is known that the significance value of the partner support variable is 0.000 $(p<0.05)$, which means that partner support contributes negatively to parenting stress. The higher the partner's support, the lower the parenting stress.

The significance value of $F$ is $0.000(p$ $<0.05$ ), so it can be concluded that the research hypothesis is accepted. Islamic religious coping and partner support variables contribute simultaneously (together) to parenting stress. In addition, it is known that the calculated $\mathrm{F}$ value is 32,236 . In other words, the variables of partner support and Islamic religious coping simultaneously contribute to parenting stress.

The value of the coefficient of determination or $\mathrm{R}$ square is 0.164 (16.4\%). That is, the variable Islamic religious coping and partner support simultaneously contribute to parenting stress by $16.4 \%$. While the rest $(83.6 \%)$ is influenced by other variables outside this regression equation or variables that are not examined.

The results of the regression analysis on each aspect of Islamic religious coping are known to be positive aspects of religious coping, obtained a significance value of 0.000 ( $\mathrm{p}<0.05$ ), which means that the positive aspects of religious coping contribute significantly negatively to parenting stress. In the negative aspect of religious coping, a significance value of 0.014 ( $p<0.05)$ was obtained, which means that the negative aspect of religious coping contributed significantly negatively to parenting stress.
Furthermore, on the partner support variable, it is known that in the emotional attention aspect, a significance value of 0.000 $(p<0.05)$ was obtained, in the instrumental support aspect, a significance value of 0.543 ( $p>0.05$ ) was obtained, the significance value in the information support aspect was 0.55 ( $>>0.05) .0 .05)$ and the significance value on the aspect of award support is 0.081 ( $p>0.05$ ). Based on these results, it is known that the aspect of emotional attention is the most significant aspect that contributes negatively to parenting stress.

The researcher also conducted different tests on each category of demographic characteristics of the research subjects, to see the extent of the differences in the three research variables in each demographic characteristic. The results of the different tests on the demographic characteristics of this study can be seen in the following table:

Table 6.

Demographic Characteristics Difference Test Results

\begin{tabular}{|c|c|c|c|c|c|c|}
\hline $\begin{array}{l}\mathbf{N} \\
\mathbf{0} \\
.\end{array}$ & $\begin{array}{c}\text { Var } \\
\text { iabl } \\
\mathbf{e}\end{array}$ & $\begin{array}{c}\text { Demog } \\
\text { raphic } \\
\text { Charac } \\
\text { teristic } \\
\text { s }\end{array}$ & $\begin{array}{c}\text { Categor } \\
\mathbf{y}\end{array}$ & $\begin{array}{c}\mathbf{M} \\
\mathbf{e a} \\
\mathbf{n} \\
\mathbf{R a} \\
\mathbf{n k}\end{array}$ & $\begin{array}{l}\text { Si } \\
\text { g. }\end{array}$ & $\begin{array}{c}\text { Infor } \\
\text { matio } \\
\mathbf{n}\end{array}$ \\
\hline \multirow[t]{3}{*}{1} & $\begin{array}{l}\text { Isla } \\
\text { mic } \\
\text { relig } \\
\text { ious } \\
\text { copi } \\
\text { ng }\end{array}$ & Age & $26-40$ & $\begin{array}{r}16 \\
2.7 \\
4 \\
14 \\
8.4 \\
3\end{array}$ & $\begin{array}{r}0 . \\
27 \\
4\end{array}$ & $\begin{array}{l}\text { No } \\
\text { differ } \\
\text { ence. }\end{array}$ \\
\hline & $\begin{array}{l}\text { Part } \\
\text { ner } \\
\text { supp } \\
\text { ort }\end{array}$ & Age & $26-40$ & $\begin{array}{r}15 \\
6.2 \\
2 \\
17 \\
5.9 \\
8\end{array}$ & $\begin{array}{r}0 . \\
13 \\
2\end{array}$ & $\begin{array}{l}\text { No } \\
\text { differ } \\
\text { ence. }\end{array}$ \\
\hline & $\begin{array}{l}\text { Pare } \\
\text { ntin } \\
\mathrm{g} \\
\text { stres } \\
\mathrm{s}\end{array}$ & Age & $26-40$ & $\begin{array}{r}16 \\
5.6 \\
4 \\
13 \\
6.1 \\
6 \\
\end{array}$ & $\begin{array}{r}0 . \\
02 \\
5\end{array}$ & $\begin{array}{l}\text { There } \\
\text { is a } \\
\text { differ } \\
\text { ence. }\end{array}$ \\
\hline $\begin{array}{l}2 \\
.\end{array}$ & $\begin{array}{l}\text { Isla } \\
\text { mic } \\
\text { relig } \\
\text { ious } \\
\text { copi } \\
\text { ng }\end{array}$ & $\begin{array}{l}\text { Numbe } \\
\text { r of } \\
\text { childre } \\
n\end{array}$ & $1-4$ & $\begin{array}{r}16 \\
0.4 \\
1 \\
12 \\
7.3 \\
8\end{array}$ & $\begin{array}{r}0 . \\
47 \\
5\end{array}$ & $\begin{array}{l}\text { No } \\
\text { differ } \\
\text { ence. }\end{array}$ \\
\hline & & & & IS & 2 & $\begin{array}{l}2-728 X \\
9-6468\end{array}$ \\
\hline
\end{tabular}




\begin{tabular}{|c|c|c|c|c|c|c|}
\hline & \multirow{2}{*}{$\begin{array}{l}\text { Paer } \\
\text { tner } \\
\text { supp } \\
\text { ort }\end{array}$} & \multirow{2}{*}{$\begin{array}{l}\text { Numbe } \\
\mathrm{r} \text { of } \\
\text { childre } \\
\mathrm{n}\end{array}$} & $1-4$ & $\begin{array}{r}16 \\
1.2 \\
7\end{array}$ & \multirow[t]{2}{*}{$\begin{array}{r}0 . \\
02 \\
9\end{array}$} & \multirow{2}{*}{$\begin{array}{l}\text { There } \\
\text { is a } \\
\text { differ } \\
\text { ence. }\end{array}$} \\
\hline & & & $>5$ & $\begin{array}{r}60 . \\
00\end{array}$ & & \\
\hline & \multirow{6}{*}{$\begin{array}{l}\text { Pare } \\
\text { ntin } \\
\mathrm{g} \\
\text { stres } \\
\mathrm{s}\end{array}$} & \multirow{6}{*}{$\begin{array}{l}\text { Numbe } \\
\mathrm{r} \text { of } \\
\text { childre } \\
\mathrm{n}\end{array}$} & $1-4$ & 15 & \multirow{6}{*}{$\begin{array}{r}0 . \\
55 \\
5\end{array}$} & \multirow{6}{*}{$\begin{array}{l}\text { No } \\
\text { differ } \\
\text { ence. }\end{array}$} \\
\hline & & & & 9.6 & & \\
\hline & & & & 6 & & \\
\hline & & & $>5$ & 18 & & \\
\hline & & & & 7.0 & & \\
\hline & & & & 0 & & \\
\hline \multirow{44}{*}{$\begin{array}{l}3 \\
.\end{array}$} & \multirow{15}{*}{$\begin{array}{l}\text { Isla } \\
\text { mic } \\
\text { relig } \\
\text { ious } \\
\text { copi } \\
\text { ng }\end{array}$} & \multirow{15}{*}{$\begin{array}{l}\text { Level } \\
\text { of } \\
\text { educati } \\
\text { on }\end{array}$} & Element & 25 & \multirow{15}{*}{$\begin{array}{r}0 . \\
16 \\
3\end{array}$} & \multirow{15}{*}{$\begin{array}{l}\text { No } \\
\text { differ } \\
\text { ence. }\end{array}$} \\
\hline & & & ary & 2.5 & & \\
\hline & & & & 0 & & \\
\hline & & & JHS/Tsa & 14 & & \\
\hline & & & nawiyah & 9.0 & & \\
\hline & & & & 8 & & \\
\hline & & & SHS/SM & 17 & & \\
\hline & & & K/Aliya & 8.7 & & \\
\hline & & & $\mathrm{h}$ & 7 & & \\
\hline & & & Undergr & 16 & & \\
\hline & & & aduate & 1.7 & & \\
\hline & & & diploma & 7 & & \\
\hline & & & Masters & 13 & & \\
\hline & & & & 4.8 & & \\
\hline & & & Doctoral & 4 & & \\
\hline & \multirow{14}{*}{$\begin{array}{l}\text { Cou } \\
\text { ple } \\
\text { supp } \\
\text { ort }\end{array}$} & \multirow{14}{*}{$\begin{array}{l}\text { Level } \\
\text { of } \\
\text { educati } \\
\text { on }\end{array}$} & Element & 38. & \multirow{14}{*}{$\begin{array}{r}0 . \\
41 \\
8\end{array}$} & \multirow{14}{*}{$\begin{array}{l}\text { No } \\
\text { differ } \\
\text { ence. }\end{array}$} \\
\hline & & & ary & 00 & & \\
\hline & & & JHS/Tsa & 12 & & \\
\hline & & & nawiyah & 9.2 & & \\
\hline & & & & 5 & & \\
\hline & & & SHS/VH & 15 & & \\
\hline & & & S/Aliyah & 2.1 & & \\
\hline & & & & 5 & & \\
\hline & & & Undergr & 15 & & \\
\hline & & & aduate & 9.7 & & \\
\hline & & & diploma & 3 & & \\
\hline & & & Masters & 17 & & \\
\hline & & & & 4.5 & & \\
\hline & & & Doctoral & 1 & & \\
\hline & Pare & Level & Element & 15 & 0. & No \\
\hline & ntin & & ary & 1.0 & 06 & differ \\
\hline & $\mathrm{g}$ & educati & & 0 & 1 & ence. \\
\hline & stres & & JHS/Tsa & 26 & & \\
\hline & $\mathrm{s}$ & & nawiyah & 0.4 & & \\
\hline & & & & 2 & & \\
\hline & & & SHS/VH & 14 & & \\
\hline & & & S/Aliyah & 6.9 & & \\
\hline & & & & 3 & & \\
\hline & & & Undergr & 15 & & \\
\hline & & & aduate & 7.2 & & \\
\hline & & & diploma & 2 & & \\
\hline & & & Masters & 17 & & \\
\hline & & & and & 1.9 & & \\
\hline & & & Doctoral & 3 & & \\
\hline 4 & Isla & Job- & Housewi & 14 & 0. & There \\
\hline & mic & status & $\mathrm{fe}$ & 7.9 & 00 & is $\mathrm{a}$ \\
\hline & relig & & & 5 & 6 & differ \\
\hline & ious & & Work & 17 & & ence. \\
\hline & copi & & & 0.9 & & \\
\hline & $n g$ & & & 6 & & \\
\hline
\end{tabular}

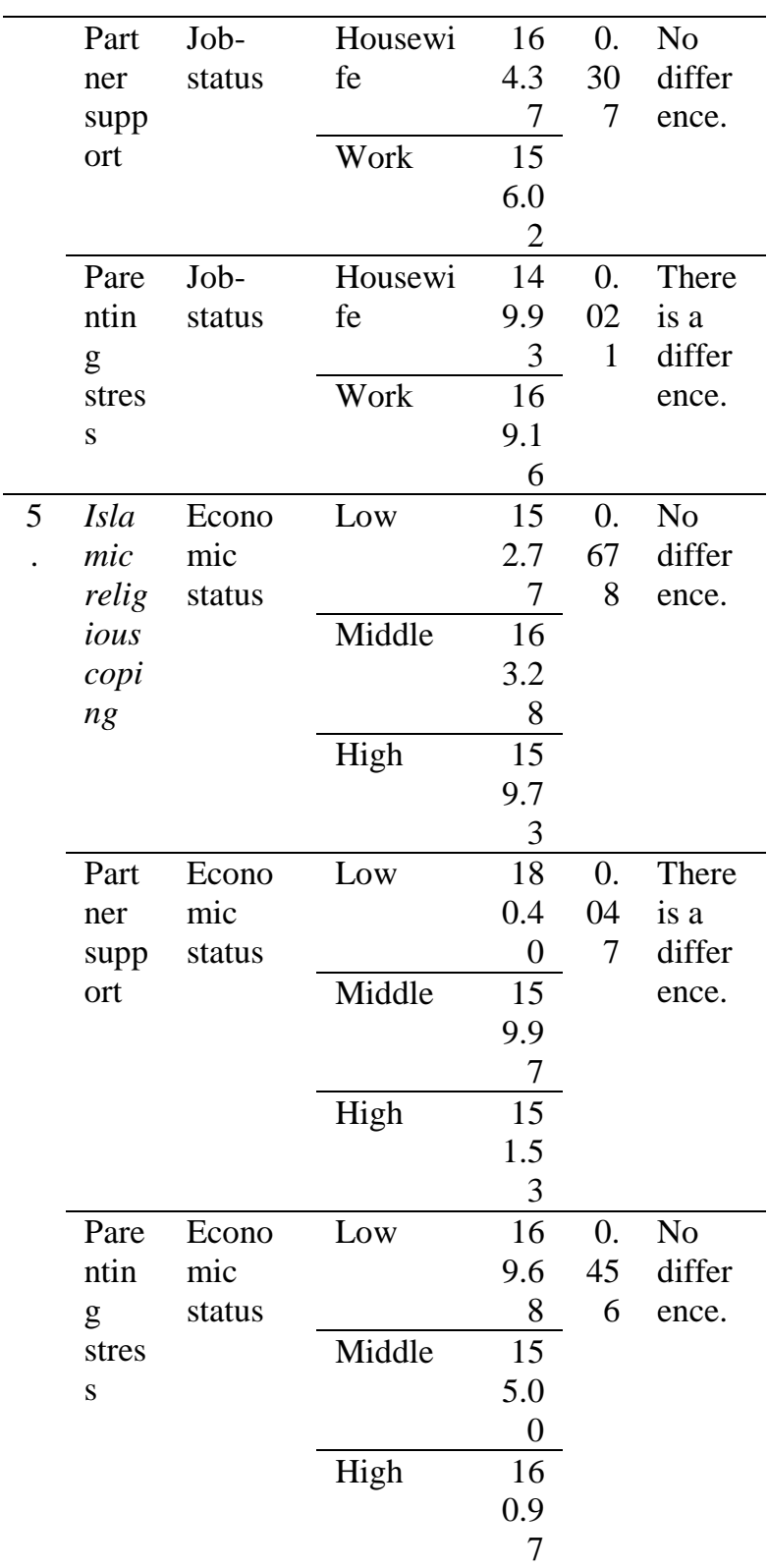

Table 6 above shows some of the findings. First: there are differences in parenting stress among mothers of different age groups. The 26-40 year age group had higher parenting stress than the 41-51 year age group. Second: there is no difference in parenting stress seen from the number of children being cared for. Mothers who have more than five or more children experience parenting stress compared to mothers who have less than five children.

Third: there is no significant difference in parenting stress based on the mother's education level. Mothers with junior high school education experience parenting stress 
comparable to mothers with elementary, high school, undergraduate, and master/doctoral education levels. Fourth: there are differences in parenting stress on housewives and working mothers, where working mothers experience higher parenting stress than housewives. Fifth: there is no difference in parenting stress in terms of economic status. Mothers with lower economic status experience parenting stress comparable to mothers with middle and higher economic status.

\section{Discussion}

The results of this study indicate that there is a significant negative contribution between Islamic religious coping and partner support for parenting stress for mothers who accompany SFH children in the COVID-19 pandemic situation. When mothers have high Islamic religious coping abilities, it will have an impact on reducing maternal parenting stress in accompanying SFH children. Vice versa, when a mother has low Islamic religious coping abilities, it will increase parenting stress. This proves that Islamic religious coping is important in contributing to minimizing parenting stress experienced by mothers when accompanying SFH children.

The results of this study support previous research (Narges, 2016) that religious coping has a significant and negative relationship with parenting stress. Religiosity is a factor that can predict the prevention of problems that occur in the process of caring for a family. The results of this study also support the opinion of Mahoney (2010) that religiosity contributes to reducing parenting stress. Religious coping is one of the factors that can predict family resilience and significantly contributes to parenting stress.

Islam plays an important role in the ability of a Muslim to overcome difficult situations in his life (Raiya, 2008). Carver et al (1989) suggest the reason someone applies religiosity as a coping strategy, namely because religion is a person's emotional resource in facing difficult situations. Furthermore, religious coping can foster a person's positive perspective in looking at problems. Referring to the definition of Islamic religious coping put forward by Raiya et al, (2008) It is known that Islamic religious coping is a strategy to understand negative events by relating them to something sacred. With Islamic religious coping, a mother who experiences parenting stress in this pandemic situation will be able to have a positive attitude, so that it will reduce the parenting stress she experiences.

The importance of remembering and having faith in Allah when faced with problems has also been ordered by Allah. This can be seen from the word of Allah in the Qur'an Surah At-Talaq: 2-3:

Meaning: "and whoever is minful of Allah, He will make a way out for them. And will provie for him from where he does not expect. And whoever relies upon Allah - then $\mathrm{He}$ is sufficient for him. Indeed, allah will accomplish His purpose. Allah has already set for everything." (QS. at-Talaq: 2-3).

The verse explains that those who fear Allah, are not only given and facilitated a way out of the difficulties they face but they are also provided with sustenance by Allah from unexpected directions. Furthermore, Allah calls for them to put their trust in Him, because it is Allah who provides for their needs and makes their affairs successful (Ministry of Religion of the Republic of Indonesia, 1971).

The same applies to a mother who accompanies SFH's children in this COVID-19 pandemic situation. If a mother has faith in her piety to God in accompanying SFH children during this pandemic, then this will help minimize the parenting stress she experiences.

Furthermore, the results of the study found a significant negative contribution between partner support and parenting stress. That is, when a mother gets the support of a 
partner, it will affect the decrease in maternal parenting stress in accompanying children while undergoing SFH. Vice versa. When a mother does not get her husband's support, it will increase parenting stress. This finding is supported by previous research that the husband's support affects parenting stress.

The thing he bags is in line with the expression Guidubaldi et al (2010) that partner support is one of the important factors to reduce the level of parenting stress because it has a high relationship with partner involvement when assisting in parenting. Partner support can reduce parenting stress experienced by mothers (Kanter \& Proulx, 2019). Greenglass et al (2006) in their research found that support from other people in providing information, advice, encouragement, and emotional support can help a person become more positive in solving a problem. Social support provided by relatives, in particular, such as partner and family members, plays a protective role. This support is important in reducing the effects of stress on women's physical and psychological health (Razurel et al, 2011).

If the partner provides positive support, it can minimize parenting stress (Boyd, 2002). A partner or husband who can give attention, appreciation, help, encouragement, advice, and the availability of time can make the mother enjoy her role as a parent (Irbah et al, 2011).

In the Islamic perspective, the role of the partner or father in parenting is emphasized several times in the Qur'an. One of them, in Surah At-Tahrim: 6, Allah commands all men and women of faith (in this case including the father) to protect their families from the fire of hell.

Meaning: "O you who believed, protect yourselves and your families from a hellfire whose fuel is people and stones; guardians of the angels who are harsh, harsh, and do not disobey Allah in what He commands them and always do what is commanded.." (QS. atTahrim: 6).

Allah SWT in the verse above emphasizes fathers to be involved in the parenting process, so that children or families will be spared from the torments of hellfire. Likewise concerning SFH's assistance in this COVID-19 pandemic situation. The learning process at home is a vital opportunity for the presence of the role of a partner or father to contribute to assisting children in learning. This is because it will strengthen a good emotional relationship between father and son. In addition, the role of partner in accompanying SFH children also greatly contributes to the increased burden of responsibility for a mother during this pandemic. Therefore, with the presence of partner support and involvement, it is hoped that it will minimize the occurrence of parenting stress on the mother.

Based on further analysis of the different tests, it is known that there are differences in parenting stress in mothers with different age groups. This is following previous research that parenting stress is influenced by age (Dearter \& Deckard, 2004). In this study, it was found that women aged 2640 years had higher parenting stress than those aged 41 years and over. This happens related to the experience of living various challenges of life. Women over the age of 40 have a more diverse and tough life experience than women aged 40 and under.

Furthermore, differences in parenting stress also occur in housewives and working mothers, where working mothers experience higher parenting stress than housewives. This is following previous research that working mothers are more susceptible to parenting stress than mothers who do not work because work responsibilities outside the home are quite time-consuming to carry out their childcare role to the fullest (Plant \& Sanders, 2007). 
The result of further analysis on the aspects of partner support found that of the four aspects of partner support (emotional attention, instrumental support, informational support, and reward support) the most contributing to parenting stress was emotional attention. The results of regression analysis on aspects of emotional attention showed a significance value of $0.000(\mathrm{p}<0.05)$ which means that this aspect contributed very significantly to parenting stress.

The indicators of emotional attention given by partners include routinely asking about the partner's condition, not ignoring the problems faced by the partner, taking time to discuss, listening to the partner's complaints, and understanding the partner's feelings when problems are overwritten. This shows that support in the form of emotional attention is a very important form of support and is needed by a mother in carrying out her role of caring for children. When mothers get emotional support from their partners, it will help reduce the parenting stress experienced.

Furthermore, Islamic religious coping and simultaneous partner support can contribute to parenting stress for mothers accompanying SFH children during this pandemic. In line with this, previous research has proven that religious coping and social support are factors that contribute to psychological stress (Vasquez, 2010).

Patterns of coping strategies and social support also contribute to the ability of parents to raise children(Khan \& Alam, 2016). Based on these findings, if a mother has Islamic religious coping abilities and simultaneously gets support from her partner, then the mother will avoid the stress of parenting.

\section{Conclusion}

Islamic religious coping and partner support are two important things that cannot be separated from the parenting process. This is because it will contribute to parenting stress (either simultaneously or partially) for mothers who accompany SFH children during the COVID-19 pandemic.

Suggestions for further researchers. Future researchers are expected to develop further research through other research methods, such as experiments so that they can provide special skills to mothers who accompany SFH children in this pandemic situation. It is hoped that this will help improve the ability of mothers in terms of cognitive, affective, and conative so that it will help improve the psychological well-being of mothers in accompanying SFH children. In addition, it is also possible for further researchers to conduct experimental research on fathers or husbands so that they can synergize with their wives in caring for children and accompanying SFH in this pandemic situation.

Suggestions for the community, especially husbands (fathers), to be able to provide support to their wives (mothers) in the process of raising children during this pandemic. Fathers are expected to be able to provide support in the form of emotional attention, such as routinely asking about the wife's condition, not ignoring the problems faced by her wife, spending time discussing with her wife, listening to her wife's complaints, and trying to understand how the wife feels when her wife is hit by problems in life. Through this support, it is hoped that fathers (husbands) can help minimize the stress of parenting mothers (wives) in accompanying SFH children during this pandemic.

\section{References}

Abidin, R., Flens, J. R., \& Austin, W. G. (2013). The parenting stress index. In Forensic Uses of Clinical Assessment Instruments.

https://doi.org/10.4324/9780203726587

Achour, M., \& Boerhannoeddin, A.B. (2011). The Role of Religiosity as a Coping Strategy in Coping with Work-Family Conflict: The Case of Malaysian Women in Academia. International Journal of Social Science and Humanity (pp. 8085).

https://doi.org/10.7763/ijssh.2011.v1.14 
Aflakseir, A., \& Coleman, P. G. (2009). The influence of religious coping on the mental health of disabled Iranian war veterans. Mental Health, Religion and Culture, 12(2), 175-190. https://doi.org/10.1080/13674670802428 563

Ai, A. L., Peterson, C., \& Huang, B. (2009). The International Journal for the Psychology of Religion RESEARCH: The Effect of Religious-Spiritual Coping on Positive Attitudes of Adult Muslim Refugees from Kosovo and Bosnia. The International Journal for the Psychology of Religion, 13(1), 29-47. https://doi.org/10.1207/S15327582IJPR1 301

Aini, R.N., Susanto, T., \& Rasni, H. (2020). The Relation Beetween Parenting Stress and Physical Abuse against Children With Disabilities in Special School Bondowoso. Inklusi, 7(1), 151. https://doi.org/10.14421/ijds.070107

Al-Hajjaj, I.M. (2008). Shahīh Muslim Jilid 3. Beirut: Dar Al-Kotob Al-Ilmiyah, 225.

Berry, J. O., \& Jones, W. H. (1995). The parental stress scale: Initial psychometric evidence. Journal of Social and Personal Relationships, 12(3), 463-472. https://doi.org/10.1177/02654075951230 09

Boyd, B. A. (2002). Examining the Relationship BetWeen Stress and Lack of Social Support in Mothers of Children With Autism. Focus On Autism And Other Developmental Disabilities 17(4), 208-215.

https://doi.org/10.1177/10883576020170 040301.

Brooks, J. (2011). The Process of Parenting. Eight Edition. New York: McGraww Hill Companies.

Carver, C. S., Scheier, M. F., \& Weintraub, K. J. (1989). Assessing Coping Strategies: A Theoretically Based Approach. Journal of Personality and Social Psychology, 56(2), 267-283. https://doi.org/10.1037/00223514.56.2.267

Davis, R. F., \& Kiang, L. (2020). Parental stress and religious coping by mothers of children with autism. Psychology of Religion and Spirituality. https://doi.org/10.1037/rel0000183

Deater-Deckard, K. (2004). Parenting stres: Current perspective in Psychology. New Haven and London: Yale University Press.

Depag RI. (1971). Al- Qur'an dan Terjemahnya. Jakarta: Depag.

Dorio, J. M. (2010). The provision of spousal support: Antecedents, consequences, and crossover effects. Dissertation Abstracts International: Section B: The Sciences and Engineering, 71(2-B), 1380. http://search.ebscohost.com/login.aspx?d irect $=$ true $\& \mathrm{db}=$ psyh $\& A N=2010-99160$ $437 \&$ site $=$ ehost-live \&scope $=$ site

Elmes, D.G., Kantowitz, B.H., \& Roediger, H.L. (2014). Metode Penelitian dalam Psikologi. Jakarta: Salemba Humanika.

Greenglass, E., Fiksenbaum, L., \& Eaton, J. (2006). The relationship between coping, social support, functional disability and depression in the elderly. Anxiety, Stress and Coping, 19(1), 15-31. https://doi.org/10.1080/14659890500436 430

Greenhaus, J. H., Parasuraman, S., \& Wormley, W. M. (1990). Effects of Race on Organizational Experience, Job Performance Evaluations, and Career Outcomes. Academy of Management Journal, 33(1), 64-86. https://doi.org/10.2307/256352

Guidubaldi, J., Cleminshaw, H. K., Guidubaldi, J., \& Cleminshaw, H. K. (2010). The Development of the Cleminshaw-Guidubaldi Parent Satisfaction Scale. Journal of Clinical Child Psychology 37-41. https://doi.org/10.1207/s15374424jccp14 04

Hadi, S. (2004). Statistik Jilid 2. Yogyakarta: Penerbit Andi.

Hasibuan, M.A.I., Anindhita, N., Maulida, N.H., \& Nashori, F. (2018). Hubungan antara Amanah dan Dukungan Sosial dengan Kesejahteraan Subjektif Mahasiswa Perantau. Psikohumaniora Jurnal Penelitian Psikologi, 3(1), 101116. 
Hastings, R. P., Daley, D., Burns, C., \& Beck, A. (2006). Maternal distress and expressed emotion: Cross-sectional and longitudinal relationships with behavior problems of children with intellectual disabilities. American Journal on Mental Retardation

111,1 . https://doi.org/10.1352/08958017(2006)111[48:MDAEEC]2.0.CO;2

Holly, L. E., Fenley, A. R., Kritikos, T. K., Merson, R. A., Abidin, R. R., \& Langer, D. A. (2019). Evidence-Base Update for Parenting Stress Measures in Clinical Samples. Journal of Clinical Child and Adolescent Psychology, 48(5), 685-705. https://doi.org/10.1080/15374416.2019.1 639515

Irbah, W.N.F., Supraptiningsih, E., Hamdan, S. R. (2018). Hubungan dukungan suami dengan parenting stress pada ibu dengan anak moderate mental retardation. Prosiding Psikologi, 4(2), 440-446. http://karyailmiah.unisba.ac.id/index.php/ psikologi/article/view/11101.

Johnston, C., Hessl, D., Blasey, C., Eliez, S., Erba, H., Dyer-Friedman, J., Glaser, B., \& Reiss, A. L. (2003). Factors associated with parenting stress in mothers of children with fragile $\mathrm{X}$ syndrome. Journal of Developmental and Behavioral Pediatrics. https://doi.org/10.1097/00004703200308000-00008

Kanter, J. B., \& Proulx, C. M. (2019). The longitudinal association between maternal parenting stress and spousal supportiveness. Journal of Family Psychology. https://doi.org/10.1037/fam0000478

Kementerian Pemberdayaan Perempuan dan Perlindungan Anak. (2020). Pengasuhan dan Peningkatan Psikologis di Era New Normal Harus Memenuhi Hak Anak. https://www.kemenpppa.go.id/index.ph $\mathrm{p} /$ page/read/29/2715/pengasuhan-danpeningkatan-psikologis-di-era-newnormal-harus-memenuhi-hak-anak. (Diakses pada 9 Oktober 2020).

Khan, M. F., \& Alam, M. A. (2016). Coping Trends of Parents Having Children With Developmental Disabilities: a Literature
Review. European Journal of Special Education Research, 39-49.

Khan, Z. H., Watson, P. J., Chen, Z., Iftikhar, A., \& Jabeen, R. (2012). Pakistani religious coping and the experience and behaviour of Ramadan. Mental Health, Religion and Culture. https://doi.org/10.1080/13674676.2011.5 82862

Kompas. (2020). Ibu yang Bunuh Anak karena Susah Belajar Online Sempat Mengaku Putrinya Hilang. https://megapolitan.kompas.com/read/20 20/09/16/12204241/ibu-yang-bunuhanak-karena-susah-belajar-onlinesempat-mengaku-putrinya? page $=$ all. (Diakses pada 9 Oktober, 2020).

Lu. M-H, Wang, G-H, Lei, H., Shi, M-L., Zhu, R., \& Jiang, F. (2018). Social Support as Mediator and Moderator of the Relationship Between Parenting Stress and Life Satisfaction Among the Chinese Parents of Children with ASD. Journal of Autism and Developmental Disorders, 48, 1181-1188.

https://doi.org/10.1007/s10803-0173448-y.

Mahoney, A. (2010). Religion in families, 1999-2009: A relational spirituality framework. Journal of Marriage and Family, 72(4), 805-827. https://doi.org/10.1111/j.17413737.2010.00732.x

Marliani, R., Nasrudin, E., Rahmawati, R., \& Ramdani, Z. (2020). Regulasi Emosi, Stres, dan Kesejahteraan Psikologis: Studi Pada Ibu Work from Home dalam Menghadapi Pandemi COVID-19. Jurnal Psikologi, 1. https://www.researchgate.net/publication /34115070

Narges, C. (2016). The Role of Iranian Religious coping in Mothers Parenting Stress with Autistic Children. Journal of Knowledge \& Research in Applied Psychology, 16, 4 (62), 61-68. https://www.sid.ir/en/journal/ViewPape r.aspx?id=483862. (Diakses pada 9 Oktober 2020).

Pargament, K. I., Koenig, H. G., \& Perez, L. M. (2000). The many methods of 
religious coping: Development and initial validation of the RCOPE. Journal of Clinical Psychology, 56(4), 519-543. https://doi.org/10.1002/(SICI)10974679(200004)56:4<519::AIDJCLP6>3.0.CO;2-1

Pargament, K., Feuille, M., \& Burdzy, D. (2011). The Brief RCOPE: Current psychometric status of a short measure of religious coping. Religions, 2(1), 51-76. https://doi.org/10.3390/rel2010051

Patel, C. J., Beekhan, A., Paruk, Z., \& Ramgoon, S. (2008). Work-family conflict, job satisfaction and spousal support: an exploratory study of nurses' experience. Curationis, 31(1), 38-44. https://doi.org/10.4102/curationis.v31i1. 906

Pinderhughes, E. E., Bates, J. E., Dodge, K. A., Pettit, G. S., \& Zelli, A. (2000). Discipline responses: Influences of parents' socioeconomic status, ethnicity, beliefs about parenting, stress, and cognitive-emotional processes. Journal of Family Psychology 14, 3. https://doi.org/10.1037/08933200.14.3.380

Plant, K. M., \& Sanders, M. R. (2007). Predictors of care-giver stress in families of preschool-aged children with developmental disabilities. Journal of Intellectual Disability Research, 51(2), 109-124. https://doi.org/10.1111/j.13652788.2006.00829.x

Raiya, H. (2008). A Psychological Measure of Islamic Religiousness: Evidence for relevance, reliability and validity. Dissertation Abstracts International: Section B: The Sciences and Engineering.

Raiya, H. A., Pargament, K., Mahoney, A., \& Stein, C. (2008a). A psychological measure of islamic religiousness: Development and evidence for reliability and validity. International Journal for the Psychology of Religion, 18(4), 291-315. https://doi.org/10.1080/10508610802229 270

Raiya, H. A., Pargament, K., Mahoney, A., \& Stein, C. (2008b). A psychological measure of islamic religiousness: Development and evidence for reliability and validity. International Journal for the Psychology of Religion. https://doi.org/10.1080/10508610802229 270

Ratnasari, K.A \& Kuntoro. (2017). Hubungan Parenting Stress, Pengasuhan dan Penyesuaian Dalam Keluarga Terhadap Perilaku Kekerasan Anak Dalam Rumah Tangga. Jurnal Manajemen Kesehatan (3) 1 .

Razurel, C., Bruchon-Schweitzer, M., Dupanloup, A., Irion, O., \& Epiney, M. (2011). Stressful events, social support and coping strategies of primiparous women during the postpartum period: A qualitative study. Midwifery, 27(2), 237242.

https://doi.org/10.1016/j.midw.2009.06.0 05

Sari, D. M. P., Lestari, C. Y. D., Putra, E. C., \& Nashori, F. (2018). Kualitas hidup lansia ditinjau dari sabar dan dukungan sosial. Jurnal Ilmiah Psikologi Terapan, 6(2), 131-141. https://doi.org/10.22219/jipt.v6i2.5341

Shihab, Q. (2009). Tafsir Al-Mishbah. Jakarta: Lentera Hati.

Siddik, I.N., Oclaudya, K., Ramiza, K., \& Nashori, F. Kebermaknaan hidup ODHA ditinjau dari ikhlas dan dukungan sosial. Psikoislamedia Jurnal Psikologi, 3(1), 98114. KEBERMAKNAAN HIDUP ODHA DITINJAU DARI IKHLAS DAN DUKUNGAN SOCIAL | Siddik Psikoislamedia : Jurnal Psikologi

Stella, A., \& Chima, O. (2015). Work-Family Balance and Coping Strategies among Women: Evidence from Commercial Banks in Nigeria. 7(2), 152-161.

Sugiyono. (2019). Statistika untuk Penelitian. Bandung: Penerbit Alfabeta.

Tirto.id. (2020). Survei KPAI: Kekerasan Anak Akibat Beratnya Beban Ibu saat COVID19. https://tirto.id/survei-kpaikekerasan-anak-akibat-beratnya-bebanibu-saat-covid-19-fS2L. (Diakses pada 9 Oktober 2020).

UNICEF. (2020). COVID-19 dan Anak-Anak di Indonesia: Agenda Tindakan untuk Mengatasi Tantangan Sosial Ekonomi. https://www.unicef.org/indonesia/media 
/4646/file/COVID-19\%20dan\%20anakanak\%20di\%20Indonesia.pdf (Diakses pada 11 Oktober 2020).

Vasquez, P. (2010). Religious Coping and Social Support as Mediators and / or Moderators and Acculturative Stress in a Latino Community Sample.

Wilcox, W. B. (2002). Religion, convention, and paternal involvement. Journal of Marriage and Family, 64(3), 780-792. https://doi.org/10.1111/j.17413737.2002.00780.x

World Health Organization (WHO). (2020). Pertanyaan dan Jawaban Terkait Virus Corona.

https://www.who.int/indonesia/news/nov el-coronavirus/qa-for-public (Diakses pada 11 Oktober 2020).

Zarei, J., Rostami, R., \& Ghapanchi, A. (2010). Marital satisfaction in parents of children with attention deficit/hyperactivity disorder in comparison with parents of normal children. Procedia-Social and Behavioral Sciences, 5, 744-747. https://doi.org/10.1016/j.sbspro.2010.07. 177 